\title{
Katolička crkva u Istri i agrarna reforma (1946. - 1948.) - primjer Pazinskog dekanata
}

\author{
Izvorni znanstveni rad \\ Original scientific paper
}

UDK 282(497.5-3 Istra):332.33.021.8>"1946/1948“

\begin{abstract}
Autor u članku na temelju arhivskoga gradiva analizira posljedice „Odluke o uređenju agrarnih odnosa i poništenju dražbi na području Oblasnog Narodnog odbora za Istru" od 26. studenoga 1946. za Katoličku crkvu u Istri. U prvome dijelu prikazana je opća situacija, u kojoj istarska Crkva pokušava dokazati kako će je provođenje spomenute "Odluke“ dovesti na „prosjački štap“, čime će doći u pitanje i njezino funkcioniranje te kolizija "Odluke" s republičkim Zakonom o agrarnoj reformi. U drugome dijelu predstavljena je situacija u Pazinskome dekanatu (12 župa i 1 samostalna kapelanija). Različitost u prikazu veličine zemljišnih posjeda - koji su bili u vlasništvu pojedinih župa - između crkvenih i državnih ustanova upućuje, s jedne strane, na složenost zemljišno-vlasničkih odnosa, a s druge, na različite metodologije u izračunu te veličine.
\end{abstract}

Ključne riječi: Jugoslavija, Hrvatska, Katolička crkva u Istri, Pazinski dekanat, agrarna reforma

\section{Uvod}

$\mathrm{O}$ snovni normativni akt kojim je jugoslavenska „narodna vlast“ nastojala riješiti pitanje zemljišno-vlasničkih odnosa bio je Zakon o agrarnim odnosima i kolonizaciji, koji je jednoglasno izglasan u Privremenoj narodnoj skupštini DFJ u Beogradu 23. kolovoza 1945. Polazeći od načela da „zemlja pripada onomu tko je obrađuje“, a s ciljem njegova ostvarivanja, taj je Zakon odredio eksproprijaciju velikih zemljišnih posjeda kako bi se stvorio zemljišni fond, iz kojega bi se dodijelila zemlja seljacima bezemljašima ili onima s nedovoljno zemlje. Na udaru eksproprijacije našli su se i „(...) zemljišni posedi crkava, manastira, i verskih ustanova i svih zadužbina, svetovnih i verskih." ${ }^{1} \mathrm{Na}$ temelju saveznoga Zakona, sukladno s uobičajenom jugoslavenskom praksom, trebalo je donijeti i republičke zakone, koji bi uvažili povijesne i društvene specifičnosti pojedinih federalnih jedinica, dakako bez nekoga značajnijeg odstupanja od saveznoga Zakona. Tako je 24. studenoga 1945. Predsjedništvo Narodnoga Sabora Hrvatske donijelo Zakon o provođenju agrarne reforme i kolonizacije na području Federalne Hrvatske. Tim je Zakonom „običnim“ vjerskim ustanovama (crkvama, samostanima i zakladama) ostavljen zemljišni maksimum od 10 ha, a onima "(...) većeg značenja ili veće historijske važnosti (...)" moglo je ostati do 30 ha obradive površine i do 30 ha šume. O tome koje su vjerske ustanove spadale u drugu, „povlaštenu“ kategoriju 
u svakome će pojedinom slučaju odlučivati Ministarstvo šumarstva i poljoprivrede u suglasnosti s Predsjedništvom Vlade NRH. ${ }^{2}$

Od potpisivanja Beogradskoga sporazuma 9. lipnja 1945. između predstavnikâ vladâ Velike Britanije i SAD-a s jedne te jugoslavenske Vlade s druge strane, do Pariškoga mirovnog ugovora 10. veljače 1947., koji su potpisale Italija i pobjedničke sile, među kojima je bila i Jugoslavija, vodila se diplomatsko-politička borba za Istru između Italije i jugoslavenske vlasti. U tome razdoblju najveći je dio Istre, tzv. zona „B“, imao poseban položaj. Vrhovnu vlast imala je VUJA. Civilnim (upravnim) organima vlasti bili su NOO-i ${ }^{3}$ na čelu s ONOI-jem. Pri Socijalnomu Odjelu ONOI-ja 8. srpnja 1945. osnovana je peteročlana Oblasna komisija za agrarnu reformu, koja je već 12. srpnja započela s radom. Njezin zadatak bio je prikupiti podatke o stanovništvu na području ONOI-ja, kao i o broju zaprežne stoke, seoske sirotinje, kulaka i veleposjednika, uključujući i Crkvu te ustanoviti koliki je broj onih koji su se željeli iseliti u plodnije krajeve Jugoslavije. Kao glavnu poteškoću u svojim nastojanjima za prikupljanje podataka o imanjima iznad 50 ha, koji su bili označeni veleposjedima i podvrgnuti agrarnoj reformi, kao i o posjedima koje sami vlasnici nisu obrađivali, Komisija je navodila činjenicu da se u mnogim kotarskim uredima nisu mogli pronaći posjedovni listovi, dok su neki kotarski uredi, poput onoga u Motovunu, bili uništeni. U međuvremenu je izglasan gore spomenut Zakon o agrarnoj reformi, koji je Komisiju stavio pred nove zadatke: „Rad se s jedne strane morao proširiti, a s druge suziti. ${ }^{4}$

Dana 26. studenoga 1946. ONOI je donio „Odluku o uređenju agrarnih odnosa i poništenju dražbi", kojom se u Istri ukidaju kolonatski odnosi ${ }^{5}$ bez obzira na njihovo trajanje, a napoličarski ${ }^{6}$ i drugi zakupnički odnosi prestaju postojati ako su trajali duže od petnaest godina, počevši unatrag od 8. rujna 1943., dok se sve dražbe, koje su se izvršile u vrijeme fašizma od 1922., a čiji je cilj bio uništavanje domaćega slavenskog stanovništva, poništavaju. ${ }^{7}$ Time seljaci - koloni - postaju vlasnicima zemlje, dok su napoličari i drugi zakupnici postajali vlasnicima samo ako su zemlju obrađivali duže od petnaest godina. Početkom 1947. Izvršni odbor ONOI-ja imenovao je sedam članova Oblasne agrarne komisije, a za predsjednika je izabran Vjekoslav Ladavac. ${ }^{8}$

2 „Zakon o provođenju agrarne reforme i kolonizacije“, Narodne novine, br. 80, Zagreb, 26. studenoga 1945. O oduzimanju imovine Katoličkoj crkvi detaljnije u: Akmadža 2003; 2005.

3 Općim zakonom o narodnim odborima, koji je donio Prezidijum Narodne skupštine FNRJ 21. svibnja 1946., NOO-i su preimenovani u NO-e. Službeni list FNRJ, br. 43, Beograd, 28. svibnja 1946.

4 HR-DAPA-79, ONO za Istru, kut. 662, fasc. Poljoprivreda, Izvještaj Komisije za agrarnu reformu, br. 104/45, Labin, 22. studenoga 1945.

5 Kolonat je vrsta ugovora o zakupu kojim vlasnik zemljišta na određeno vrijeme daje zemlju na obradu slobodnomu seljaku (kolonu). Potonji se obvezuje da će zemlju obrađivati kao „dobar težak“ te da će vlasniku davati dio uroda, kao što je to precizno naznačeno u ugovoru. Budući da se kolonat tretirao kao privatno-pravni ugovor, u Dalmaciji i Istri (posebice u nekadašnjemu mletačkom dijelu Istre) zadržao se sve do 1946. (Pezo 2007: 596).

6 Slično kao i u kolonatu, vlasnik daje drugomu zemlju na obradu. Obrađivač (napoličar) obvezuje se da će vlasniku davati dio uroda, a obično je to bila polovina, odakle i proizlazi naziv napoličarstvo. O pravnoj naravi napoličarstva postoje različita mišljenja, od toga da se radi o ugovoru o zakupu ili ortaštvu do toga da je to ugovor sui generis. (Pezo 2007: 784).

7 „Odluka o uređenju agrarnih odnosa i poništenju dražbi na području Oblasnog NO za Istru“, Službeni list DFJ, br. 19, 1. prosinca 1946.; HR-DAPA-80, Oblasna agrarna komisija, kut. 1, fasc. Spisi 2-100, Oblasna agrarna komisija, Odjel šumarstva i šumske industrije, br. 107/47, Labin, 15. siječnja 1947. Dražbe, odnosno javne prodaje ovrhom zaplijenjenih nekretnina ili pokretnina provodile su se zbog neplaćanja poreza ili dugova. Dakako, bilo bi pogrešno svim dražbama davati nacionalno-politički karakter. Neke su nastale zbog dugovanja bankama ili privatnicima. HR-DAPA-80, Oblasna agrarna komisija, kut. 3, Elaborat nepoznatog pravnika o agrarnoj reformi u Istri. Nema datuma niti naslovnika komu je upućen, no iz konteksta se može iščitati da je pisan krajem 1947. ili početkom 1948.

8 HR-DAPA-80, Oblasna agrarna komisija, kut. 1, fasc. Spisi 301-399, ONO za Istru, Tajništvo, br. 302, Labin, 2. siječnja 1947. 
Provođenje „Odluke“ povjereno je Oblasnoj agrarnoj komisiji i kotarskim agrarnim komisijama, koje su se tek trebale osnovati. Predviđalo se da će šume, pašnjaci i livade, koji će se agrarnom reformom oduzeti dotadašnjim vlasnicima, prijeći u vlasništvo mjesnih NO-a. To je dovelo do nekontrolirane sječe šuma od strane donedavnih vlasnika, ali i do zakupnikâ tih šuma. Kako bi se svladala teškoća glede devastacije šuma, ONOI je donio naredbu „(...) o najstrožoj zabrani (...)“ sječe drveća u šumi, na livadama ili pašnjacima bez dopuštenja nadležnog NO-a. ${ }^{9}$

\section{Nedoumice oko zakonskih odredaba}

„Odluka“ ONOI-ja izazvala je uznemirenost među istarskim biskupima i svećenicima, koji su strahovali da bi Crkva u Istri mogla ostati gotovo bez ikakvih posjeda. Razlog je tomu, s jedne strane, taj što većinu crkvenih posjeda u Istri nisu obrađivali vlasnici (župnik, biskupija ili samostan), nego se ona davala u razne vrste zakupa, dok se, s druge strane, sve do potpisivanja mirovnoga sporazuma s Italijom nije mogao primijeniti jugoslavenski Zakon o agrarnoj reformi, odnosno hrvatski Zakon o provođenju agrarne reforme. ${ }^{10}$

Božo Milanović je u više navrata upozoravao da će provođenje „Odluke o uređenju agrarnih odnosa" Crkvu u Istri dovesti u lošiji materijalni položaj u usporedbi s drugim dijelovima države. Kao član Komisije za vjerske poslove Vlade NRH obraćao se predsjedniku Vlade Vladimiru Bakariću i ministru u Vladi, svećeniku mons. Svetozaru Ritigu, s molbom za ukidanjem „Odluke“ ONOI-ja. lako je imao njihovo obećanje da se spomenuta "Odluka“ neće odnositi na crkveno zemljište u Istri, Oblasna je agrarna komisija požurivala njezino provođenje upravo na crkvenim imanjima. ${ }^{11}$ Dakako, sve je to dodatno opteretilo odnose između lokalne vlasti i Katoličke crkve u Istri.

Istarsko je svećenstvo strahovalo da kolizija između Zakona o agrarnoj reformi i „Odluke o uređenju agrarnih odnosa" ONOI-ja može stvoriti zbrku s neželjenim političkim posljedicama. Pretpostavljao se ovakav mogući scenarij: prema „Odluci“ ONOI-ja seljak napoličar ili kolon u vlasništvo dobiva crkvenu zemlju, koju će, pak, kasnije - kada se jugoslavenski zakoni budu primjenjivali na Istru - na temelju Zakona o agrarnoj reformi istu zemlju u okviru zemljišnoga maksimuma od 10 ha morati vratiti Crkvi. Sve bi to izazvalo ogorčenje kod seljaka i nepovjerenje ne samo prema državi, nego i prema Crkvi. Ukaz Prezidijuma Narodne skupštine FNRJ od 15. rujna 1947. o proširenju važnosti Ustava i zakonâ FNRJ na područje nekadašnje zone „ $B$ “ otvorio je prostor za primjenu dviju zakonskih odredaba o agrarnoj reformi - „jugoslavenske“ i „,istarske“ - tim više što se u Ukazu navodilo da raniji pravni propisi i odredbe koje su donijeli organi narodne vlasti „(...) ostaju na snazi ukoliko nisu protivni saveznim i republičkim zakonima i drugim pravnim propisima. ${ }^{12}$ ONOI je još u svibnju 1947. donio „Odluku o obvezatnoj primjeni zakona i ostalih općeobvezatnih pravnih propisa koji važe u FNRJ, odnosno u NRH na području Oblasnog narodnog odbora za Istru“. O tome koji se savezni, odnosno republički zakoni neće „(...) bilo u cijelosti, bilo djelomično (...)“ primjenjivati na području Oblasti Istre trebao je odlučiti Izvršni odbor ONOI-ja. ${ }^{13} \mathrm{Na}$ taj

9 HR-DAPA-80, Oblasna agrarna komisija, kut. 1, fasc. Spisi 2-100, ONO za Istru, Odjel šumarstva i šumske industrije, br. 107/47, Labin, 15. siječnja 1947.

10 Vidi bilj. 1 i 2.

11 AH IKD, OF BM, kut. CUI, fasc. b.o, Predstavka B. Milanovića Komisiji za vjerske poslove, Pazin, 18. prosinca 1947.

12 „Ukaz o proširenju važnosti Ustava, zakona i drugih pravnih propisa FNRJ na području pripojenom teritoriju FNRJ po ugovoru o miru s Italijom“, Službeni list FNRJ, br. 80, Beograd, 17. rujna 1947.

13 HR-DAPA-79, ONO za Istru, kut. 625, fasc. Zapisnici 1947., Odluka ONO-a za Istru, br. 4615/47, Pazin, 10. svibnja 1947. 
je način ostalo nejasno je li „Odluka“ ONOI-ja od 26. studenoga 1946. protivna saveznim zakonima.

Da bi se izbjegnule neželjene posljedice primjene dvaju zakona, iz crkvenih je redova došao prijedlog da se od spomenute "Odluke“ ONOI-ja od 26. studenoga 1946. izuzmu crkveni posjedi. Taj se zahtjev opravdavao činjenicom da bi se primjenom „Odluke“ od 26. studenoga Katolička crkva u Istri našla u goremu položaju nego u drugim dijelovima Hrvatske i Jugoslavije, „(...) jer oblasni zakon i agrarna reforma nju bi oštetili dvaput, što se u Jugoslaviji nigdje nije dogodilo. " ${ }^{14}$ Svećenici su također predlagali da se - nakon primjenjivanja Zakona o agrarnoj reformi u Istri - Crkvi dopusti raspolaganje posjedima iznad 10 ha, i to iz dvaju razloga. Ako se u plodnijim dijelovima Jugoslavije, primjerice, u Slavoniji i Banatu, Crkvi ostavilo 10 ha, tada bi se na istarskome području Crkvi trebalo ostaviti najmanje 15 ha „prhke“ oranice i 5 ha pašnjaka i šume. Tim bi se viškom moglo plaćati sakristana, zvonara, orguljaša i druge župne pomoćnike, koje će biti teško isplaćivati ako Crkvi na raspolaganju ostane samo 10 ha. ${ }^{15}$

Jedan od problema u razrješavanju zemljišnoga čvora bilo je i to što je Crkva u Istri dio svojih zemljišnih posjeda stekla dobrovoljnom ostavštinom vjernikâ. Darovatelji su najčešće tražili da im se zauzvrat služe tzv. fundirane mise. ${ }^{16} \mathrm{U}$ slučaju oduzimanja zemlje bilo bi teško udovoljiti preuzetoj obvezi održavanja tih misa. Umjesto izražavanja nezadovoljstva prema bogatstvu Crkve, svećenici su smatrali da bi bilo puno bolje kada bi vlast mjesne odbore, koji su provodili agrarnu reformu, uputila da objasne seljacima kako se od prihoda s crkvenih imanja nabavljaju stvari potrebne za liturgiju, počevši od crkvene odjeće, svijećâ i tamjana do crkvenih knjiga. Ne bi se smjela zanemariti ni povijesno-socijalna osjetljivost svećenika za svoje vjernike jer su poput seljačkih sinova svećenici dijelili njihovu sudbinu. Seljacima je također trebalo jasno reći da se svećenici u ondašnje vrijeme nisu protivili pravednoj podjeli zemlje, već su se pitali kako će se odvijati pastoralan rad Crkve u slučaju oduzimanja zemljišnih posjeda - vrlo često jedinoga izvora prihoda. Nakon takvih bi objašnjenja seljaci zasigurno bili umjereniji u svojim zahtjevima za crkvenim posjedima. ${ }^{17}$

Međutim, i prije "Odluke“ ONOI-ja od 26. studenoga 1946. stvarale su se zakonske pretpostavke za revolucionarnu preobrazbu istarske društvene zbilje. Odmah nakon oslobođenja, pojedini su odjeli ONOI-ja, u skladu s odlukama AVNOJ-a od 24. studenoga 1944. o konfiskaciji imovine njemačkih građana i narodnih neprijatelja, započeli s provođenjem konfiskacije. No, kada ni novoosnovane komisije za konfiskaciju i sekvestraciju pri Upravnim odjelima kotarskih NO-a nisu bile za to da se dovoljno brzo i učinkovito provedu mjere konfiskacije i sekvestracije, Oblasna uprava narodnih dobara za Istru odlučila je u svaki kotar postaviti povjerenike, „(...) kojima će biti dužnost da pomažu drugovima iz Komisije za konfiskaciju i sekvestraciju i da primaju upute od Oblasne uprave narodnih dobara kojoj će biti odgovorni." Velik je, pak, broj napuštenih dobara diljem čitave Istre nametao potrebu zapošljavanja novih ljudi, ali i nabave motornoga vozila, a sve s ciljem učinkovitije konfiskacije. $^{18}$

14 HDA, FKVP, kut. 29, fasc. Opći spisi 1-600, Zbor svećenika sv. Pavla za Istru, br. 42/46, Pazin, 12. prosinca 1946. $\mathrm{Na}$ ist. mj.

16 Zavjetne mise. Onaj tko je ostavio posjed Crkvi zauzvrat je tražio da se za pokoj njegove duše iz godine u godinu drže mise. Peuzimajući posjed, Crkva je preuzimala i obvezu ispunjavanja pokojnikove oporuke. (Šetka 1976: 347).

17 HDA, FKVP, kut. 129, fasc. Opći spisi 1- 600, Zbor svećenika sv. Pavla za Istru, br. 42/46, Pazin, 12. prosinca 1946.

18 HR-DAPA-79, ONO za Istru, kut. 604, fasc. Zapisnici 1945/46, Zapisnik sa sjednice Oblasne uprave narodnih dobara, Labin, 3. srpnja 1945. 
Odluka ONOI-ja od 17. travnja 1946. da se poslovi konfiskacije i sekvestracije prenesu u nadležnost kotarskih sudova očito nije dala nekakve rezultate. ${ }^{19} \mathrm{Na}$ sastanku predstavnika Javnoga tužiteljstva za Istru, Okružnoga suda i Odsjeka za narodnu imovinu ONOI-ja u Labinu, koji se održao u studenome 1946., ustanovljeno je kako bi, unatoč brojnim objektivnim teškoćama, posebice pomanjkanju kadrova i novca, sudovi trebali uspješnije obavljati svoj posao. Kako bi se to i ostvarilo, Predsjedništvo Okružnoga narodnog suda trebalo je na sastanak pozvati kotarske narodne sudove te ih upozoriti na potrebu ozbiljnoga shvaćanja poslova oko sekvestracije i konfiskacije, Odsjek za narodnu imovinu trebao je pronaći nove, stručne ljude za obavljanje pojedinih poslova, pri čemu će troškove oko zapošljavanja novih ljudi snositi Okružni narodni sud, koji će od Oblasnoga NO-a preuzeti već odobren kredit za te troškove. Sve poslove oko sekvestracije trebalo je privesti kraju do 10. studenoga $1946 .{ }^{20}$

\section{Agrarna reforma u Pazinskome dekanatu}

Pazinski dekanat ${ }^{21}$ kao dio Tršćanske i Koparske biskupije, odnosno Pazinske apostolske administrature od $1947 .{ }^{22}$, u vremenskome isječku koji je predmet ovoga rada obuhvaćao je dvanaest župa ${ }^{23}$ i jednu samostalnu kapelaniju. ${ }^{24}$ Radilo se o sljedećim župama: Beram, Grdoselo, Kašćerga, Kringa, Pazin, Stari Pazin, Sv. Matej-Cere, Sv. Petar u Šumi, Tinjan, Trviž, Zamask i Žminj, dok je Kršikla imala status samostalne kapelanije. ${ }^{25}$ Svaki je župnik preuzimanjem župe dobivao i beneficij (nadarbinu), koji se u povijesti sastojao od crkvene desetine, župnoga lukna, rente od crkvenih zemljišta ili zgrada te doprinosa vjernika za neke crkvene obrede. ${ }^{26} \mathrm{Na}$ udaru agrarne reforme našao se onaj dio beneficija koji su činili zemljišni posjedi, a manjim dijelom i zgrade. Budući da je jedan dio tih posjeda služio za potrebe uzdržavanja crkve, a drugi za osobne potrebe župnika, u crkvenim se dokumentima redovito spominje crkveni (beneficij župne crkve) i župni beneficij, dok državne statistike te posjede navode pod jedinstvenim nazivom - crkveni beneficij. Osim za Zamask i Kašćergu, o kojima nisam pronašao službene (državne) statistike, za druge su župe, usporedbe radi, najprije navedeni podaci župnih ureda, a potom i Kotarske agrarne komisije u Motovunu. Do ukidanja kotara Motovun u ožujku 1947. župe Pazinskoga dekanata nalazile su se u sastavu spomenutoga kotara.

1. Beram. Od beneficija župne crkve, površine 18 ha, Kotarska agrarna komisija u Motovunu oduzela je $3 \mathrm{ha}, 22$ ara i $35 \mathrm{~m}^{2}$. To znači da je tomu beneficiju ostalo $14 \mathrm{ha}, 77$ ara i $65 \mathrm{~m}^{2}$. Župnomu beneficiju, veličine 5 ha, 39 ara i $59 \mathrm{~m}^{2}$ ista je Komisija oduzela 1 ha, 77 ara i $3 \mathrm{~m}^{2}$. Ostala su mu 3 ha, 62 ara i $56 \mathrm{~m}^{2}$. Dakle, od 23 ha, 39 ara i $59 \mathrm{~m}^{2}$, koliko su ukupno

19 HR-DAPA-79, ONO za Istru, kut. 604, fasc. Zapisnici 1945/46, Odluka Oblasnog NO-a od 17. travnja 1946, br. 3345, Zapisnik od 2. rujna 1946.

20 HR-DAPA-79, ONO za Istru, kut. 625, fasc. Zapisnici 1947., Odluka ONO-a za Istru, br. 4615/47, Pazin, 10. svibnja 1947.

21 Prema odredbama kanonskoga prava, biskup-ordinarij je teritorij svoje biskupije dijelio na dekanate - područja od nekoliko župa. Na čelu dekanata nalazi se dekan, kojega imenuje biskup. Precizno su određena prava i obveze dekana prema biskupu kao višoj razini vlasti i župnicima dekanata kao nižoj razini. (Odar 1944: 186-188).

22 Administraturu su činili hrvatski dekanati Pazin, Pićan, Kršan i istočni dio dekanata Oprtalj te slovenski dekanati Postojna i Sežana. (Pamić 1978: 21).

23 Župa je dio biskupije, kojim uime biskupa upravlja župnik. Predstavlja osnovnu, pravno samostalnu jedinicu za udovoljavanje vjerskih potreba mjesne Crkve. (Rebić 2002: 1062).

24 Riječ kapelanija ima višestruko i složeno značenje. Ovdje se radi o tipu kapelanije, kojim kapelan upravlja samostalno, a ne kao župnikov delegat, kao što je to bio slučaj s drugim tipovima kapelanija. (Fino 1933: 456).

25 BAP, Crkvene obavijesti, ožujak 1955., Status Crkve u Istri prema stanju na dan 31. prosinca 1954.

26 Vidaković-Mukić 2006: 575. 
iznosili crkveni posjedi (beneficij župne crkve i župni beneficij), agrarnom reformom oduzeta su 4 ha, 99 ara i $38 \mathrm{~m}^{2}$. Crkveni su posjedi i dalje ostali relativno veliki (18 ha, 40 ara i 21 $\left.\mathrm{m}^{2}\right) .{ }^{27}$ Prema državnim podacima, beneficij župne crkve iznosio je okruglih 20 ha. Agrarnom reformom od crkvenoga beneficija oduzeta su samo 2 ha i 25 ara, dok je od onoga župnoga, veličine 5 ha, oduzet 1 ha i 75 ara. ${ }^{28}$

Župni ured Beram zamolio je Ministarstvo poljoprivrede da se za uzdržavanje povijesne crkve sv. Marije na Škriljinah, koju krase freske iz 15. st. i glagoljski grafiti, na osnovi čl. 18. Zakona o agrarnoj reformi župi dopusti zemljišni maksimum od 30 ha obradive površine i 30 ha šuma. ${ }^{29}$ Molba je odbijena, a župi Beram „(...) ne priznaje se svojstvo ustanove veće historijske vrijednosti jer za to ne postoje uvjeti. “30 Nakon odlaska u Sloveniju beramski je župnik Josip Grašić biskupu Fogaru poklonio vinograd. Kotarska agrarna komisija dodijelila je biskupov vinograd Antonu Milohaniću jer ga je ovaj obrađivao više od dvadeset godina. ${ }^{31}$

2. Grdoselo. Postojao je samo župni beneficij - župna kuća i zemljište koje je narod zvao „plovanijskim“ - a raspolagao je površinom malo većom od 18 ha. Agrarnom reformom 1947. jedna manja parcela, čija površina nije navedena, dodijeljena je mještaninu Josipu Drndiću..$^{32}$ Kotarska agrarna komisija Motovun navodi da je veličina župnoga beneficija bila 19 ha, od čega ništa nije oduzeto. ${ }^{33}$

3. U Kašćergi je župni vrt - površine 2 ara i $9 \mathrm{~m}^{2}$, ograđen kamenim zidom, bio zasađen s 12 loza, ispletenih u odrinu („ruzu“), tri breskve i nekoliko grmova lovora te ružičnjakom i cvjetnjakom, koji su ukrašavali crkvu, kao i povrtnjakom za potrebe župnika - oduzet župnomu beneficiju radi izgradnje seoske cisterne („šterne“). Župnik Milivoj Barković je predstavnicima NO-a kotara Pazin - koji su ga posjetili 31. listopada 1947. te mu priopćili namjeru izgradnje cisterne u župnome vrtu - uzalud dokazivao da bi bilo logičnije cisternu izgraditi na seoskom trgu, i to iz više razloga. Na trgu je bilo više mjesta, a cisterna bi se brže i lakše punila jer je trg okružen kućama, s čijih bi se krovova u cisternu slijevala kišnica. Usto, u blizini župnoga vrta nalazila su se odlagališta za gnoj, pa bi otjecanje vode iz odlagališta u cisternu ugrozilo njezinu kvalitetu. No, odbornici su ostali uporni u svojemu zahtjevu - za izgradnju „šterne“ u obzir je dolazio samo župni vrt. ${ }^{34}$

Kotarske su vlasti obećale župniku da će mu za onaj dio vrta, u kojemu će biti izgrađena cisterna, dodijeliti površinu cjelokupnoga vrta u jednome od susjednih vrtova, dok će ostatak vrta oko cisterne s lozama, ružičnjakom i povrtnjakom ostati u vlasništvu župne nadarbine; pritom se zidovi nisu smjeli dirati, osim za otvaranje dvaju ulaza. U slučaju oduzimanja čitavoga vrta župnoj nadarbini nadoknadit će se njegova stvarna vrijednost. lako župnik niti usmeno niti pisano nije prihvatio ponudu, 29. prosinca 1948. počele su pripreme za podizanje cisterne. U suprotnosti s obećanjem, zidovi su srušeni do temelja, loze su posječene „(...) i na nekulturan način poništeno sve što je bilo još rastućeg u vrtu.“${ }^{\text {“35 }}$

BAP, Fond poslije 1945., Župa Beram, Župni ured Beram, 4. siječnja 1948.

28 HR-DAPA-80, Oblasna agrarna komisija, kut. 2, fasc. Pregled stanja crkvenih posjeda Kotarske agrarne komisije Motovun, za godinu 1948.

29 BAP, Fond poslije 1945., Župa Beram, Ministarstvo poljoprivrede, Odjel za agrarnu reformu i kolonizaciju, br. 4, 5. veljače 1948.

30 BAP, Fond poslije 1945., Župa Beram, Ministarstvo poljoprivrede, Odjel za agrarnu reformu i kolonizaciju, br. 2530-VII-1948, Zagreb, 26. veljače 1948.

31 BAP, Fond poslije 1945., Župa Beram, Kotarska agrarna komisija u Pazinu, br. 186/I, 10. siječnja 1948.

32 BAP, Fond poslije 1945., Župa Grdoselo, Izvještaj za kanonsku vizitaciju, Sastavio Andrija Bonefačić, župnik, Pazin, 23. svibnja 1953.

33 HR-DAPA-80, Oblasna agrarna komisija, kut. 2, fasc. Pregled stanja crkvenih posjeda Kotarske agrarne komisije Motovun, za godinu 1948.

34 BAP, Fond poslije 1945., Župa Kašćerga, Župni ured Kašćerga, br. 1/1948, 12. svibnja 1948.

35 Na ist. mj. 
Ipak, u cjelini, župni beneficij i beneficij župne crkve, ukupne površine 6 ha i 30 ara, nisu došli pod udar agrarne reforme. Sama se, pak, Agrarna komisija kotara Pazin prilikom dolaska u Kašćergu nije izjasnila je li oduzimanje vrta učinjeno po Zakonu. No, opravdanje je pronašla u odredbi Zakona o eksproprijaciji po kojemu je država mogla izvršiti prisilnu eksproprijaciju zemljišta ako je ono bilo neophodno za državne potrebe. ${ }^{36}$

Tek poslije tri godine župnik Barković je u listopadu 1951., uz suglasnost administratora Nežića, prihvatio ponudu da kao kompenzaciju za oduzeti vrt dobije drugi, malo veći vrt, stoga mu je Mjesni NO Kašćerga izdao potvrdu. ${ }^{37}$ I biskup i župnik bili su svjesni da je vrt na kojemu je podignuta cisterna nemoguće vratiti, pa su prihvatili ponudu o zamjeni, koju su u početku odlučno odbijali. Nema podataka Kotarske agrarne komisije.

4. Kringa. Zemljišni fond župnoga i crkvenoga beneficija imao je ukupno 29 ha, 51 ar i $14 \mathrm{~m}^{2}$. Od toga je na oranice otpadalo $17 \mathrm{ha}, 59$ ara i $8 \mathrm{~m}^{2}$, na pašnjake 1 ha, 59 ara i 29 $\mathrm{m}^{2}$, na šume 8 ha, 22 ara i $62 \mathrm{~m}^{2}$, na livade 2 ha, 10 ara i $15 \mathrm{~m}^{2}$, dok je neplodni dio činilo samo 4 ara i $38 \mathrm{~m}^{2}$. U agrarnoj reformi do 1948. crkvi u Kringi oduzet je ukupno 21 ha, 25 ara i $67 \mathrm{~m}^{2}$, odnosno $13 \mathrm{ha}, 32$ ara i $2 \mathrm{~m}^{2}$ oranica, 1 ha, 5 ara i $59 \mathrm{~m}^{2}$ pašnjaka, 4 ha, 88 ara i $70 \mathrm{~m}^{2}$ šuma te 1 ha, 64 ara i $36 \mathrm{~m}^{2}$ livada. To znači da je beneficij župe Kringa spao na 8 ha, 25 ara i $47 \mathrm{~m}^{2}$, što predstavlja još jedan u nizu dokaza o radikalizaciji republičkoga Zakona o agrarnoj reformi, koji je Crkvi dopuštao zemljišni maksimum od 10 ha. ${ }^{38}$ Podaci Kotarske agrarne komisije u Motovunu ovdje se bitno razlikuju - veličina obaju beneficija iznosila je 34 ha, a u agrarnoj je reformi oduzeto samo 4 ha. ${ }^{39}$

5. Kršikla. Crkveni beneficij sastojao se od 8 ha, 84 ara i $52 \mathrm{~m}^{2}$, a župni od 96 ara i 83 $\mathrm{m}^{2} .^{40}$ Kotarski je sud u Pazinu 1962. potvrdio prethodnu odluku Kotarske agrarne komisije u Pazinu o oduzimanju crkvenom beneficiju 1 ha, 97 ara i $18 \mathrm{~m}^{2}$ (oranice, vinogradi, livade i pašnjaci), što je dodijeljeno dotadašnjim obrađivačima i korisnicima tih posjeda. ${ }^{41}$ Prema službenim podacima, na području spomenute župe crkveni su posjedi također bili veći u odnosu na crkvene: beneficij župne crkve obuhvaćao je 15 ha i 50 ara, dok je župni iznosio 1 ha, a agrarnom reformom nije ništa oduzeto. ${ }^{42}$

6. Pazin. Od župnoga beneficija, koji se sastojao od $17 \mathrm{ha}, 61$ ara i $11 \mathrm{~m}^{2}$, oduzeto je 11 ha, 48 ara i $61 \mathrm{~m}^{2}$. Jedan dio, površine $6 \mathrm{ha}, 67$ ara i $80 \mathrm{~m}^{2}$ dodijeljen je seljačkoj zadruzi IvoliĆusi, a drugi dio od 4 ha, 80 ara i $81 \mathrm{~m}^{2}$ dobila su dvojica seljaka, Antun Ćus (1 ha, 18 ara i 73 $\mathrm{m}^{2}$ ) i Jakov Gržetić ( 3 ha, 62 ara i $8 \mathrm{~m}^{2}$ ), uz objašnjenje da su kao napoličari dobivene posjede obrađivali više od petnaest godina. Beneficij župne crkve sv. Nikole, koji je iznosio 2 ha, 1 ar i $66 \mathrm{~m}^{2}$, nije se dirao. ${ }^{43}$ Prema službenim podacima, župni je beneficij bio nešto manji (12 ha i 50 ara), dok je crkveni bio isti kao i u crkvenim statistikama. Pritom je od župnoga oduzet 1 ha, a od crkvenoga 50 ara. ${ }^{44}$

7. Stari Pazin. Prije agrarne reforme crkveni posjedi imali su ukupno 4 ha, 65 ara i 69

BAP, Fond poslije 1945., Župa Kašćerga, Župni ured Kašćerga, br. 20/1948, 12. lipnja 1948.

37 BAP, Fond poslije 1945., Župa Kašćerga, Župni ured Kašćerga, NO kotara Pazin, Mjesni NO Kašćerga, 15. listopada 1951.

38 BAP, Fond poslije 1945., Župa Kringa, Inventar župne crkve u Kringi, 21. lipnja 1961.

39 HR-DAPA-80, Oblasna agrarna komisija, kut. 2, fasc. Pregled stanja crkvenih posjeda Kotarske agrarne komisije Motovun, za godinu 1947.

40 BAP, Fond poslije 1945., Kapelanija Kršikla, Župa Grimalda, 3. ožujka 1947.

41 BAP, Fond poslije 1945., Kapelanija Kršikla, Župa Grdoselo, Župni ured Grdoselo, br. 11/68, Izvještaj o oduzetoj zemlji, 3. svibnja 1968.

42 HR-DAPA-80, Oblasna agrarna komisija, kut. 2, fasc. Pregled stanja crkvenih posjeda Kotarske agrarne komisije Motovun, za godinu 1947.

43 BAP, Fond poslije 1945., Župa Pazin, Župni ured Pazin, Pazin, 6. listopada 1949.

44 HR-DAPA-80, Oblasna agrarna komisija, kut. 2, fasc. Pregled stanja crkvenih posjeda Kotarske agrarne komisije Motovun, za godinu 1947. 
$\mathrm{m}^{2}$. Agrarnom reformom oduzeta su $2 \mathrm{ha}, 12$ ara i $92 \mathrm{~m}^{2} .{ }^{45}$ Prema državnim podacima, župni je beneficij iznosio 2 ha i 50 ara, od čega je oduzet 1 ha, a od crkvenoga beneficija, koji se sastojao od 6 ha i 50 ara, oduzeta su 2 ha i 50 ara. ${ }^{46}$

8. Sv. Matej-Cere. U vlasništvu župe nalazio se beneficium simplex - mansionarij ${ }^{47}$ Žufić - površine 20 ha, 79 ara i $44 \mathrm{~m}^{2}$. Agrarnom reformom od mansionarija je oduzeto 16 ha, 39 ara i $30 \mathrm{~m}^{2}$, a ostao je manji dio od 4 ha, 40 ara i $14 \mathrm{~m}^{2} .{ }^{48} \mathrm{U}$ službenim statistikama vidljiva je nelogičnost - nije postojao ni crkveni ni župni beneficij, a podnesena je prijava (kolona i napoličara) za dodjelu 5 ha. ${ }^{49}$

9. Sv. Petar u Šumi. Od župnoga beneficija (crkvenoga nije ni bilo), površine 12 ha, 27 ara i $16 \mathrm{~m}^{2}$, nakon agrarne reforme ostalo je 10 ha, 18 ara i $53 \mathrm{~m}^{2} .{ }^{50}$ Podaci o beneficijima identični su i u državnim statistikama, no u potonjima se jedino ne navodi da je od župnoga beneficija išta oduzeto. ${ }^{51}$

10. Tinjan. Prije agrarne reforme imao je 73 ha, 4 ara i $41 \mathrm{~m}^{2}$. Agrarnom reformom ostavljen je maksimum od 10 ha, 7 ara i $92 \mathrm{~m}^{2}$, što znači da se najveći dio - 62 ha, 96 ara i 49 $\mathrm{m}^{2}$ - našao na udaru reforme. ${ }^{52}$ Kotarska komisija Motovun donosi sljedeće podatke: crkveni i župni beneficij imali su 51 ha i 5 ara zemljišta, a oduzet im je 21 ha i 50 ara. ${ }^{53}$

11. Trviž. Crkveni beneficij iznosio je 34 ha, 84 ara i $74 \mathrm{~m}^{2}$. Agrarnom reformom oduzeto je 20 ha, 5 ara i $22 \mathrm{~m}^{2}$, dok je od župnoga beneficija, veličine 4 ha, 48 ara i $65 \mathrm{~m}^{2}$, oduzet 1 ha, 94 ara i $54 \mathrm{~m}^{2} .^{54}$ Službeni podaci navode da su od crkvenoga beneficija, veličine 44 ha, oduzeta 2 ha, dok od župnoga, površine 4 ha, nije ništa oduzeto..$^{55}$

12. Zamask. Postojao je samo župni beneficij, površine 1 ha, 20 ara i $50 \mathrm{~m}^{2}$. Izrijekom se navodi da ništa nije oduzeto. ${ }^{56}$

13. Žminj. Od crkvenoga beneficija župne crkve sv. Mihovila, samostalne kapelanije sv. Kirina, područne kapelanije sv. Marije Svetomore, područne crkve sv. Foške i mansionarija Martinčić, površine 92 ha, 66 ara i $86 \mathrm{~m}^{2}$, poslije agrarne reforme 1947. i 1948. beneficiju je ostalo samo 6 ha, 69 ara i $1 \mathrm{~m}^{2}$. To znači da je oduzeto 85 ha, 97 ara i $85 \mathrm{~m}^{2}$. Najveći dio oduzete imovine dodijeljen je pojedincima, koji su kao napoličari obrađivali zemlju duže od petnaest godina ili je prešao u ruke zemljišnoga fonda. Velika jednokatnica $25 \times 6 \mathrm{~m}^{2} \mathrm{~s}$ raznim gospodarskim zgradama, koje su pripadale beneficiju područne crkve sv. Foške, 1948. proglašena je općenarodnom imovinom, s time da se njome može služiti jedan župljanin. Župni beneficij, površine 1 ha, 48 ara i $30 \mathrm{~m}^{2}$, nije bio predmetom agrarne reforme. ${ }^{57}$ Prema

45 AŽU Stari Pazin, Upitni arak o crkvenom zemljištu župe Stari Pazin, Pazin, 9. ožujka 1960.

46 HR-DAPA-80, Oblasna agrarna komisija, kut. 2, fasc. Pregled stanja crkvenih posjeda Kotarske agrarne komisije Motovun, za godinu 1947.

47 Tijekom povijesti riječ je mijenjala značenje. U konkretnome slučaju odnosi se na nadarbenika, koji je za svoju službu dobivao određenu nadarbinu (beneficij). Enciclopedia 1948 - 1954: 1979.

48 BAP, Fond poslije 1945., Župa Sv. Matej-Cere, Izvještaj za kanonsku vizitaciju, 8. siječnja 1967.

49 HR-DAPA-80, Oblasna agrarna komisija, kut. 2, fasc. Pregled stanja crkvenih posjeda Kotarske agrarne komisije Motovun, za godinu 1947.

50 BAP, Fond poslije 1945., Župa Sv. Petar u Šumi, Izvještaj za kanonsku vizitaciju, 16. travnja 1948.

51 HR-DAPA-80, Oblasna agrarna komisija, kut. 2, fasc. Pregled stanja crkvenih posjeda Kotarske agrarne komisije Motovun, za godinu 1947.

52 BAP, Fond poslije 1945., Župa Tinjan, Odluku za Tinjan po agrarnom zakonu NRH izdala Oblasna agrarna komisija za Istru, br. 1909/48, Pazin, 15. listopada 1948. (prijepis).

53 HR-DAPA-80, Oblasna agrarna komisija, kut. 2, fasc. Pregled stanja crkvenih posjeda Kotarske agrarne komisije Motovun, za godinu 1947.

54 BAP, Fond poslije 1945., Župa Trviž, Izvještaj za kanonsku vizitaciju, 16. veljače 1963.

55 HR-DAPA-80, Oblasna agrarna komisija, kut. 2, fasc. Pregled stanja crkvenih posjeda Kotarske agrarne komisije Motovun, za godinu 1947.

56 BAP, Fond poslije 1945., Župa Zamask, Izvještaj za kanonsku vizitaciju, 20. kolovoza 1965.

57 BAP, Fond poslije 1945., Župa Žminj, Izvještaj za kanonsku vizitaciju, Sastavio Rudolf Zafran, župnik, 14. rujna 1956. 
Kotarskoj komisiji Motovun crkveni posjedi površine 70 ha u agrarnoj su reformi ostali netaknuti. ${ }^{58}$

Podaci crkvene provenijencije pokazuju da je Katolička crkva na području Pazinskoga dekanata prije agrarne reforme bila vlasnikom zemljišta, površine 329 ha, 53 ara i $89 \mathrm{~m}^{2}$. U agrarnoj reformi od 1946. do 1948. Crkvi je na području toga dekanata oduzeto 231 ha, 27 ara i $50 \mathrm{~m}^{2}$ (72,18\%), a ostalo joj je 98 ha, 26 ara i $39 \mathrm{~m}^{2}(29,82 \%)$. Prema državnim statistikama, Crkva je na istome području imala posjede veličine 298 ha, od čega joj je agrarnom reformom oduzet samo 31 ha i 50 ara. Nerazmjer crkvenih i službenih statistika moguće je tumačiti činjenicom da službene statistike Kotarske agrarne komisije Motovun obuhvaćaju razdoblje do početka 1947. jer je kotar Motovun ukinut u ožujku 1947., dok crkvene obuhvaćaju još čitave dvije godine - 1947. i 1948. S druge strane, izgleda da su prisutne i dvije metodologije - crkvena, koja prikazuje sve ono što je oduzeto, i službena, koja vjerojatno prikazuje samo ono što je prešlo u zemljišni fond, ali ne i ono što su dobili koloni i napoličari. U svemu ne treba zanemariti nastojanje službenih podataka da namjerno ublaže mjere agrarne reforme prema Crkvi.

\title{
POPIS KRATICA
}

$\begin{array}{ll}\text { AH IKD } & \text { Arhiv Istarskog književnog društva Juraj Dobrila u Pazinu } \\ \text { AŽU STARI PAZIN } & \text { Arhiv župnog ureda Stari Pazin } \\ \text { BAP } & \text { Biskupijski arhiv u Poreču } \\ \text { CUI } & \text { Crkva u Istri } \\ \text { DFJ } & \text { Demokratska Federativna Jugoslavija } \\ \text { FKVP } & \text { Fond Komisije za vjerska pitanja } \\ \text { HDA } & \text { Hrvatski državni arhiv u Zagrebu } \\ \text { HR-DAPA } & \text { Državni arhiv u Pazinu } \\ \text { NO } & \text { Narodni odbor } \\ \text { NOO } & \text { Narodnooslobodilački odbor } \\ \text { OF BM } & \text { Osobni fond Bože Milanovića } \\ \text { ONOI } & \text { Oblasni Narodni odbor za Istru } \\ \text { VUJA } & \text { Vojna uprava Jugoslavenske armije }\end{array}$

\section{POPIS IZVORA}

\author{
Arhivsko gradivo \\ Hrvatski državni arhiv u Zagrebu, Fond komisije za vjerska pitanja \\ Državni arhiv u Pazinu, Fond Oblasnog narodnog odbora za Istru \\ Državni arhiv u Pazinu, Fond Oblasne agrarne komisije za Istru \\ Arhiv Istarskog književnog društva „Juraj Dobrila“ u Pazinu, Osobni fond Bože Milanovića \\ Arhiv župnog ureda Stari Pazin, Fond Inventar poslije 1945. godine \\ Biskupijski arhiv u Poreču, Fond poslije 1945. godine, Župe Pazinskog dekanata
}

\section{Novine}

Narodne novine

Službeni list DFJ (FNRJ)

58 HR-DAPA-80, Oblasna agrarna komisija, kut. 2, fasc. Pregled stanja crkvenih posjeda Kotarske agrarne komisije Motovun, za godinu 1947. 


\section{POPIS LITERATURE}

\section{AKMADŽA 2003}

Miroslav Akmadža, Oduzimanje imovine Katoličkoj crkvi i crkveno-državni odnosi od 1945. do 1966. godine: primjer Zagrebačke nadbiskupije, Društvo za povjesnicu Zagrebačke nadbiskupije „Tkalčić“, Zagreb 2003.

\section{AKMADŽA 2005}

Miroslav Akmadža, „Otuđenje nadarbinskog zemljišta zbog poreznih opterećenja u Zagrebačkoj nadbiskupiji“, Tkalčić, br. 9, Zagreb 2005., 123-272.

\section{ENCICLOPEDIA 1948 - 1954}

Enciclopedia Cattolica (ur. Giuseppe PIZZARDO), sv. VII., Inno - Mapp, Città del Vaticano, 1948. - 1954.

\section{FINO 1933}

Saverio Fino, Piccola enciclopedia del beneficiato: con le leggi ecclesiastiche e i formulari degli atti principali, Società Editrice Internazionale, Torino 1933.

\section{ODAR 1944}

Alojz Odar, Zakonik cerkvenega prava, Ljubljana 1944.

\section{PAVLOVIĆ 1952}

Mato Pavlović, Agrarna reforma u Istri od godine 1946.-1948., Radovi JAZU, knj. 288, Zagreb 1952.

\section{PAMIĆ 1978}

Marijan Pamić (ur.), Istarska Crkva jedna: proslava crkvenopravnog ujedinjenja, travanj 1978., Pazin 1978.

\section{PEZO 2007}

Vladimir Pezo (ur.), Pravni leksikon, LZ MK, Zagreb 2007.

\section{REBIĆ 2002}

Adalbert Rebić (ur.), Opći religijski leksikon: A-Ž, LZ MK, Zagreb 2002.

\section{ŠETKA 1976}

Jeronim Šetka, Hrvatska kršćanska terminologija, II. izdanje, Marija, Split 1976.

\section{VIDAKOVIĆ-MUKIĆ 2006}

Marta Vidaković-Mukić, Opći pravni rječnik, Narodne novine, Zagreb 2006.

\section{SAŽETAK}

„Odluka o uređenju agrarnih odnosa i poništenju dražbi na području Oblasnog Narodnog odbora za Istru“ od 26. studenoga 1946. svojim sadržajem i ciljevima predstavlja revolucionaran zahvat na području zemljišno-vlasničkih odnosa. Naime, tom se "Odlukom" u Istri ukidaju kolonatski, napoličarski i drugi zakupnički odnosi, a seljaci postaju vlasnicima zemlje. Budući da se u Istri, s jedne strane, većina crkvenih posjeda nije obrađivala u režiji samoga vlasnika (župnik, biskupija, samostani), nego se davala u razne vrste zakupa, dok se, s druge strane, sve do potpisivanja mirovnoga sporazuma s Italijom 10. veljače 1947. nije mogao primijeniti republički „Zakon o provođenju agrarne reforme i kolonizacije na području federalne jedinice Hrvatske" od 24. studenoga 1945., koji je Crkvi dopuštao zemljišni maksimum od 10 ha, događalo se da je Crkva u Istri ostala bez dopuštenih 10 ha, a nerijetko i bez ikakvog posjeda. Sve je to dodatno opterećivalo odnose države i Crkve u Istri. Kada je Prezidijum Narodne skupštine FNRJ 16. rujna 1947. donio Ukaz o proširenju važnosti Ustava i zakonâ FNRJ na područje nekadašnje zone „B“, u Istri se nerijetko nastavilo s provođenjem agrarne reforme prema „Odluci“ ONOI-ja iz 1946. Nastojanja „Zbora svećenika sv. Pavla za Istru“, staleške organizacije istarskoga hrvatskog svećenstva, koja je inače bila kooperativna 
prema novoj vlasti, da se ublaži oštrica agrarne reforme prema Crkvi, u pravilu nisu davala rezultate.

Prema crkvenim statistikama, na području Pazinskoga dekanata (12 župa i jedna samostalna kapelanija), odnosno dijela središnje Istre, crkveni zemljišni posjedi obuhvaćali su 329 ha, 53 ara i $89 \mathrm{~m}^{2}$. Od toga je, prema istim izvorima, tijekom agrarne reforme do 1948. oduzeto 231 ha, 27 ara i $50 \mathrm{~m}^{2}$. Prema podacima Kotarske agrarne komisije u Motovunu, u župama Pazinskoga dekanata Crkva je bila vlasnikom 298 ha, a oduzeto joj je samo 31 ha i 50 ara. Taj se nerazmjer može tumačiti različitim metodologijama u izračunu oduzetih posjeda, ali i nastojanjem vlasti da u javnosti ublaži predodžbu o restriktivnim mjerama prema Crkvi.

\section{SUMMARY}

\section{Catholic Church in Istria and Agrarian Reform (1946 - 1948) - the Pazin Deanery Example}

„The Resolution of regulation of agrarian relations and cancellation of auctions in the area of the National District committee for Istria" from November 26, 1946 with its contents and goals represents a revolutionary enterprise in the area of land-ownership relations. In other words, this "Resolution“ in Istria annuls colonial, sharecropper and other lease holding relations and peasants become land owners. Since in Istria, on the one hand, most of church lands were not cultivated by the owner itself (parish priest, diocese, monasteries) but were given in different sorts of leases, and on the other hand, until the signing of the peace treaty with Italy on February 10, 1947 the republican "Law of realization of agrarian reform and colonization on the territory of the federal unit of Croatia" from November 1945, which allowed the Church its land maximum of 10 ha could not be applied, it happened that the Church in Istria was left without its allowed 10 ha and often without any land. All of that brought additional burden to state and Church relations in Istria. When Praesidium of the National assembly of FNRJ brought the decree of the extension of significance of the FNRJ constitution and law in the former "Zone B" area in Istria on September 16, 1947, the District committee from 1946 often continued. The efforts of St. Paul's priest council, the class organization of Istrian Croatian clergy, otherwise cooperative towards the new government, to ease the edge of the agrarian reform towards the Church, as a rule gave no results.

On the Pazin deanery territory of 12 parishes and 1 autonomous curacy (part of the central Istria) church lands consisted of, according to church statistics, 329 hectares, 53 ares, $89 \mathrm{~m}^{2}$. From that, according to same sources, during the agrarian reform till 1948231 hectares, 27 ares, $50 \mathrm{~m}^{2}$ were taken away from the Church. According to the data of the Country agrarian commisson in Motovun in Pazin deanery parishes, Church was the owner of 298 hectares and only 31 ha and 50 ares were taken from it. This disproportion can be explained by different methodologies in calculation of lands which were taken away but also by government efforts to alleviate the notion of the restrictive measures towards the Church in public.

Keywords: Yugoslavia, Croatia, Catholic Church in Istria, Pazin deanery, agrarian reform 